\title{
Impact of Gender Inequalities on Women Violence: A Case Study of Ghotki District Sindh Pakistan
}

\author{
Aisha Bashir Shah \\ Assistant Professor-IBA-University of Sindh jamshoro \\ Najma Shaikh \\ Assistant Professor- Deptt:of Economics, University of Sindh jamshoro \\ Ms Albeena Mirza \\ Assistant Professor ,Department of Economics University of Sindh Jamshoro \\ Dr.Muhammd Ali Bhatti \\ Assistant Professor-IBA-Sukkur
}

\begin{abstract}
The Current research Explore the Impact of Gender inenqulities on Women Violence: A Case Study of Ghotki District Sindh Pakistan. Data were collected from 200 respondents from Ghotki and their vicinity. ResearchStudy reveals that male child preference; forced marriages in early age, illiteracy and women dependency on men are key factors of inequity on the basis of gender.Apart from that honor killing is also an evil custom victimizing the ladies since long and even increasing in the area despite the fact that literacy rate has been improved and media has played vital role for public awareness to address the issue. It was also observed that female are being dealt as slaves and male are wasting their time in unhealthy social activities in local hotels without consideration of economic responsibilities of family.
\end{abstract}

Key Words: Impact, Gender,In equalities, Women Violence.

Introduction

Gender imbalance implies unequal treatment with sexual orientations taking into account natural and physiological qualities. Sex disparity may allude to prevalence of man over his partner lady. This is approach to consider lady sub-par compared to man. Sexual orientation disparity is not defended by any general public or law. However, Pakistani instructed common society puts stock in it. Notwithstanding of, it is predominant social variable of Pakistani society especially in reverse regions of the nation. Lady in Pakistan has no respectable spot in the public arena. Still, it is prevailing trust that lady has been made just to serve man. As aftereffect of this attitude, lady has socially hassled, politically undermined and financially pushed back. This is just focal reason, why, lady has gotten to be not able assume a productive parts in the advancement of Pakistan. As of now, Pakistani lady is confronting diverse financial and political encounters that have extraordinarily undermined her potential capacities. Bad form against lady, for example, honor executing, corrosive tossing, abusive behavior at home, provocation at open places and constrained relational unions are occurring all through the nation. Lady has no free access to get instruction, to acquire for her job, to take part in basic leadership process at residential level, to possess property, to choose her marriage and to do work. The Globe Gender Gap report 2013 distributed by World Economic Forum uncovers that Pakistan is second most noticeably awful nation took after by Yemen as far as sexual orientation correspondence and reasonable dispersion of assets among man and lady. There is most likely to say that without key taking an interest of lady in financial exercises, the fantasy of more noteworthy Pakistan can't be accomplished. For reasonable advancement and advancement of any nation, lady's part is basic and vital element comparable with instance of Pakistan.

\subsection{Honor executing a Social Injustice}

The purported honor executing is known as (Karo Kari) in Sindh Pakistan. It is across the board grievous social wrongdoing against lady occurring everywhere scale. Honor slaughtering is killing of either man or lady found in infidelity or improper social relationship. In honor executing, denounced couple is being slaughtered on seeing or only on talk like sitting, mailing, seeing and strolling. However, the life of both genders is at danger. In any case, as a rule lady is disregarded and executed.

Like other piece of Sindh area, since couple of years, honor executing has likewise been winning in region Ghotki. However, its pace is getting force now in region as tribal fights get birth. In region, since back five years 45 ladies have been murdered for the sake of honor slaughtering.. In recent years 19 ladies and 6 men were punished to death in Mirpur mathelo Taulka. While in Garhi Yasin circumstance is additionally grave that inside five years 15 ladies were murdered in honor executing took after by Khanpur 11 ladies were slaughtered in same years. Plus, in $75 \%$ episodes of honor, ladies are being executed and in just $25 \%$ men are charged to capital punishment.

\section{Causes of Gender Inequality}

\subsection{Male Child variable}

In the general public of proposed zone, male tyke is favored over female kid. The vast majority of the families like to have male youngster instead of female kid. So also, young ladies are frequently denied their basic rights, for example,

\begin{tabular}{|c|c|}
\hline $\begin{array}{l}\mathbf{2 9 6 9} \mid \mathrm{P} \text { a g e } \\
\text { A ug u s t } 2016\end{array}$ & $\begin{array}{r}\text { council for Innovative Research } \\
\text { w w w cirworld. com }\end{array}$ \\
\hline
\end{tabular}


instruction, sustenance, wellbeing and marriage. Accordingly, young ladies are confronting social and financial meetings. The most devastation social issue confronted by lady in this general public is honor slaughtering. Society considers lady sub-par compared to man and that is the reason, individuals don't dither to slaughter lady rather man for the sake of honor executing.

\section{Fig: 4 Gender shrewd honor killings per 100 persons.}

\subsection{Economic Dependency}

Ladies are absolutely reliant on sensitivity of men. Ladies don't have any privilege of responsibility for property. Indeed, ladies have no privilege to gain cash for their business. The costly of fundamental necessities, for example, nourishment, fabric and wellbeing are satisfied by men. That is the reason, ladies are completely depended on sensitivity of men. Inferable from, feeble budgetary position of ladies, they are powerless against get to be casualty of honor slaughtering. In the study zone aside from Ghotki town, out of 100 just 7 to 8 ladies are occupied with formal occupation, while 92 to 93 ladies are housewives or occupied with casual occupation, for example, domesticated animals and farming. Besides, $99 \%$ of the property is claimed by men and just $1 \%$ responsibility for has a place with ladies in the study territory. This monetary shortcoming of ladies leads them to end up casualty of honor slaughtering.

\subsection{Forced Marriages}

The study in the proposed region likewise uncovered that ladies have nothing to do with choice of her marriage. Indeed, lady can't say a name of man to whom she needs to wed. In the event that she does as such, she will be executed for the sake of honor murdering. Despite what might be expected, man has got full power to pick his accomplice. He has right to choose his marriage and give his choice about his marriage, while, lady has no such right. The choice of her marriage is taken by her dad, sibling and uncle and their choice is last. Likewise, she will undoubtedly comply with their choice. On the off chance that she decreases, she will be executed for the sake of honor murdering. Our study uncovered that 25 to $30 \%$ honor slaughtering occurring because of this issue.

\section{Fig: 06 Married ladies who were requested their marriage.}

\subsection{Illiteracy}

Mass absence of education among lady is likewise fundamental driver of honor slaughtering. Our study uncovered that lone 25.3 ladies are proficient. While,75\% ladies are unskilled and among ignorant ladies around $60 \%$ don't know not their names. Plus, the absence of education rate is discovered much higher in following 30 years of age ladies, it remains at $90 \%$. Unskilled ladies don't have the foggiest idea about their rights that have been conceded to them by law. Therefore, the greater part of the ladies are living in edgy condition. Attributable to lack of education, ladies can't raise their voice against intolerable social wrongdoing, to achieve court for equity and to battle against honor murdering. Subsequently, ladies helplessness to respect slaughtering and other social wrongdoings is much higher.

\section{METHODOLOGY}

The orderly stratified specimen strategy was utilized to gather information from whole region. The information was gathered from both rustic and urban regions. An aggregate 15 towns chose from country zone of each taulka of locale and 100 family units of urban region individually. Additionally, inside every town 10 ladies matured between 20 to 30 years were met. The sorts of inquiries were already chosen in the wake of contemplating the accessible writing in news paper and specifically taking part in social exercises in provincial and urban territories. At that point, inquiries were produced for acquiring last and compelling information. Also, information was gathered in neighborhood dialect, then, it was settled, deciphered and translated in English dialect. In addition, hands on work for acquiring information of Ghotki region was done from March 15-2014 to January 25-2015.

\section{RESULTS AND DISCUSSION}

Our examination study uncovers that sex imbalance among men and ladies is the real reason for expanding honor slaughtering in Ghotki area. Sexual orientation disparity is seen in all circles of life in the area. Honor slaughtering has been expanding since couple of years in the area. Our study uncovers that inside 5 years 45 ladies are executed for the sake of honor slaughtering. Out of 45 ladies, 11 ladies are murdered in Mirpur Taulka town, trailed by 15 ladies in Khanpur Mahar town and 24 ladies in Khanpur Mahar town individually as said in fig: 01. In addition, fig: 02. Portrays that more ladies are killed in Khanpur Mahar town that record $42.2 \%$ of honor executing in the region. Plus, inquiries were requested getting information about conceivable reasons for sexual orientation imbalance in the locale that leads ladies honor executing. Around 150 ladies of every town were requested aforementioned question. Out of 150 ladies, $45 \%$ ladies trust that absence of education is real cause, trailed by $15 \%$ male kid inclination and $40 \%$ ladies trust that constrained relational unions and monetary reliance are central point that lead ladies honor murdering in the locale as specified in the fig: 04. This information uncovers that greatest ladies trust that mass lack of education among them is central point that leads slaughtering of ladies for the sake of honor murdering. Plus, fig: 03 demonstrates that more ladies are killed in honor executing however, both man and lady are similarly in charge of a corrupt demonstration. Our study uncovers that in $75 \%$ honor executing cases, ladies are being slaughtered and in just $25 \%$ cases, men are being murdered. This is a direct result of male kid inclination. Individuals trust that female is second rate compared to male and this improper discernment

\begin{tabular}{|c|c|}
\hline $\begin{array}{l}\mathbf{2 9 7 0} \mid \mathrm{P} \text { a g e } \\
\text { A ug u s t } 2016\end{array}$ & $\begin{array}{r}\text { council for Innovative Research } \\
\text { w w w cirworld. com }\end{array}$ \\
\hline
\end{tabular}


legitimize the assurance of man from killing and making lady helpless for killing for the sake of honor killing. Also, monetary dependent.

\section{Reference}

1. Bradley F, Smith, M, Long, J, O'Dowd T. Reported frequency of domestic violence: cross sectional survey of women attending general practice. BMJ 2002; 324 (7332): 271.

5. Krug EG, Mercy JA, Dahlberg LL, Zwi AB. The world report on violence and health. Lancet 2002; 360:1083-

8.

6. Rennison C. Intimate partner violence, 1993-2001. Washington (DC): Bureau of Justice Statistics, Department of Justice (US); 2003. Publication No. NCJ197838.

7. Fikree FF, Bhatti LI. Domestic violence and health of Pakistani women. International J Gynaecol Obstet 1999; 65:195-201.

8. Bettencourt A. Violence against women in Pakistan. Human Rights Advocacy Clinic; Litigation Report Spring 2000, [online] 2000 [cited 2005 November 3] 2000. Retrieved November 3]. Available from:

URL: www.du.edu/intl/humanrights/violencepkstn.pdf

9. Human Rights Watch, 'Crime or Custom?Violence against Women in Pakistan, Report of Human Rights

Watch 1999. [online][cited 2006 March]. Available from:

URL: http://www.hrw.org/reports/1999/pakistan/index.htm

10. Human Rights Commission of Pakistan (HRCP). State of human rights in 1999. Lahore: HRCP, 2000.

11. Felix Q. Honour killing and "karo kari" in Pakistan. [online] [cited 2007 May 30]. Available from:

URL: http://www.asianews.it/view.php?I= en\&art=1187: Date accessed May 30, 2007.

12. Dasgupta, S.D. Towards an Understanding of Women's Use of Non-Lethal Violence in Intimate Hetrosexual Relationships. Applied Research Forum, National Electronic Network on Violence Against Women, February 2001. [online] [cited March 2006]. Available from:

URL: http://www.vawnet.org/VNL/library/general/AR_womviol.pdf

13. Edleson JL. Primary prevention and adult domestic violence. Paper presented at the meeting of the Collaborative violence prevention initiative, San Francisco 2000.

14. Belsky, J. Child maltreatment: an ecological integration. Am Psyc 1980; 35: 320-35.

15. Heise LL. Violence against women: an integrated, ecological framework. Violence Against Women 1998; 4 : 262-90.

16. Dutton DG. Patriarchy and wife assault: The ecological fallacy. Violence Vict 1994; 9: 167-82.

17. Edleson JL, Tolman RL. Intervention for men who batter: an ecological approach. Newbury Park, CA: Sage Publication, 1992.

18. Carlson, B. Causes and maintenance of domestic violence: An ecological analysis. Social Service Review 1984; 58: 569-87.

19. Gondolf EW, Fisher ER. Battered women as survivors: An alternative to treating learned helplessness. Lexington, MA: Lexington Books, 1988.

20. Campbell J, Humphreys J. Nursing care of survivors of family violence.2nd ed. St. Louis: Mosby-Yearbook 1993.

21. Galles RJ, Cornell CP. Intimate violence in families. Beverly Hills: Sage Publications, 1985.

22. Dobash RE, Dobash RP. Women, violence and social change. New York: Routledge, 1992.

23. Dobash RE, Dobash RP. Violence against wives. New York: Free Press, 1979.

24. Hoffeler K. Battered women shattered lives. Saratoga: R \& E Publishers, 1983.

25. Schuler SR, Hashemi SM, Riley AP, Akhter S. Credit programs, patriarchy and men's violence against women in rural Bangladesh. Soc Sci Med 1996; 43: 1729-42.

26. Shaikh MA. Is domestic violence endemic in Pakistan: perspective from Pakistani wives. Pak J Med Sci 2003; 19: 23-8.

27. Visaria L. Violence against women in India: Evidence from rural Gujarat. Domestic violence in India; A summary report of three studies. Washington, DC: International Center for Research on Women (ICRW), 1999; pp 14-25. 